\title{
Nutritional and Sensory Evaluation of Enriched Gurudi (A Cassava Starch Snack Food)
}

\author{
Wordu, G. O. and Akusu, M. O.
}

\begin{abstract}
Snacks are important components of the diet. They can be eaten in place of or between meals, provide a brief supply of energy and some other nutrient. Gurudi and other cassava recipes have already been introduced to the Nigerian population. In those study, soybean flour or crayfish powder were used to enrich the gurudi and compare its acceptability as snack. Gurudi, a cassava starch snackfood was prepared using (i) cassava starch (ii) blends of cassava starch and soybean flour (iii) blends of cassava starch and crayfish powder as follows: sample control $(T G)=100 \%$ cassava storch, sample soybean enriched (SEG) $90 \%$ cassava starch plus $10 \%$ soybean flour sample crayfish powder $(C E G)=95 \%$ cassava starch plus $5 \%$ crayfish powder. Recipe of each sample was made into paste that drops by spoonfuls, thinly spread on baking sheets and oven dried. The sensory properities of each snack food sample was evaluated. The 100\% cassava starch food sample severed as control. Sensory evaluation showed no significant difference $(P>0.05)$ between the control and $10 \%$ soybean enriched sample in all the sensory attributes (colour, crispiness, taste, flavour, overall acceptability). Chemical composition of the gurudi snacks showed that the $10 \%$ say enriched sample had higher protein fiber, calcium, iron and zinc than the control.
\end{abstract}

Keywords: Gurudi, Chemical composition, flour, sensory properties, mineral elements, proximate analysis

\section{INTRODUCTION}

Snacks are important components of the diet. They can be eaten in place of, or between meals, providing a brief supply of energy or some other nutrients or they may be consumed purely for the enjoyment of their taste.

Snacking can be described as the problem free consumption of easy to handle, miniature portioned hot or colod products in solid or liquid form requiring little or no preparation and are intended to satisfy the occasional pangs of hunger. Snacks can be sweet or savoury, light or substantial and they may be endowed with attributes such as healthy or just for fun (Tettweiller, 1991).

Most snack food items are cereal based with a high starch content. These include maize flour, wheat flour, oat flour, tapioca and some modified starches can be extruded into a wide variety of textures from light, fragile, highly puffed to dense crisp products. Today's system are capable of producing flaked, shredded and expanded products based on either the traditional cooker, the single screw extruder or a system combining the twin and single screw extruder s (Ekwu, and Ehirim, 2006) flours/starches of root and tuber crops form major ingredient for snack foods and now exist simple and appropriate technologies for use of cassava flour as partial replacement of wheat flour in bread making biscuits pastries and snack foods (Ocheme O.B. 2009). Such products from flours and starches of roots and tubers are grossly deficient in proteins and other nutrients. Gurudi, a cassava starch snack food is one of such products. Gurudi is prepared mainly from cassava starch to which other ingredients such as coconut (grated) are added (Sanni et al, 2006). There is therefore, the need for enrichment of such a product nutritionally.

Gurudi and other cassava recipes have already been introduced to the Nigerian population especially in Lagos state and Rivers State as a non traditional snack food (Tettweiller 1990).

In this study, soybean flour or crayfish power was added for the enrichment of the Gurudi. And the nutritional and sensory property of the new product will be evaluated as against the existing traditional product.

\section{Materials ANd Methods}

Cassava starch soybean flour and crayfish powder were purchased from Mile III market, Port Harcourt, Rivers State, Nigeria. The reagents used in the analysis were obtained from the Department of Food Science and Technology Laboratory, Rivers State university of science and technology, Port Harcourt, Nigeria, where the work was carried out. 


\subsection{Sample Preparation}

The cassava roots were washed, cleaned of dirt and finely grated. The resulting cassava mash mixed with clean water (about 20 times the weight of the roots). Then filtered using a fine mesh sieve. The filterate was allowed to settle and the supernatant deconted within a day. The starch residue was washed off several times to act white odourless and tasteless starch the starch was put in a clean bag and pressed to dewater. The resulting cake was broken, spread thinly on trays and hot air oven dried of $60^{\circ} \mathrm{C}$ to $8 \%$ moisture. The dried starch gramies was finely milled in a hammer mill and pressed though a sieve with a size of 40 mesh. The cassava starch was packed in polyethylene bag and put in a refrigerator for further use.

The soybean flour was prepared with the seeds cleansed of extraneous materials and blanched for 20 minutes. It was put in hot air oven, dried at $60^{\circ} \mathrm{C}$. the dried soybean seeds was milled finely into flour using a hammer mill. The flour was packaged in polyethylene bag and stored in the refrigerator for further use.

The fresh crayfish was sorted to remove extraneous materials, and washed in clean water and dried in hot air oven at $50^{\circ} \mathrm{C}$ overmight. It was cooled and milled into powder using the plate mill. The milled crayfish was packaged in polyethylene bag and stored in the refrigerator for further use.

The recipe used for the reparation of gurudi are shown in table I

Table1. Recipe used for the preparation of gurudi

\begin{tabular}{|c|c|c|c|}
\hline Ingredients & \multicolumn{3}{|c|}{ Quantities in grams } \\
\hline & Traditional & Soy anriched & Crayfish anriched \\
\hline Cassava starch & 200 & 180 & 190 \\
\hline Soybean flour & - & 20 & - \\
\hline Crayfish powder & - & - & $1-$ \\
\hline Coconut (grated) & 50 & 50 & 50 \\
\hline Sugar & 25 & 25 & 25 \\
\hline Salt & 2.5 & 2.5 & 2.5 \\
\hline Nutmeg & 1.25 & 1.25 & 1.25 \\
\hline
\end{tabular}

Sourced: IITA Cassava recipes for household food security manual, 2006

\subsection{Preparation of Gurudi Snacks}

200 grams of cassava starch (Traditional gurudi) or 180 grant of cassava starch and 20 grams of soybean flour or 190 grams of cassava starch plus 10 grams of crayfish powder to each of the above was added 50 grams of grated coconut 25 gram of granulated sugar, 2.5 grams of salt and 1.25 grams of nutmeg. Each of the blend was mixed thoroughly and added with $5 \mathrm{mls}$ of water to make smooth paste that drops by spoonfuls. (Note: the soybean enriched recipe utilized additional $62 \mathrm{mls}$ of water to get smooth paste that drops by spoonfuls). Drops spread on greased baking trays and flaffened using a fork and each sample baked in an oven at a temperature of $180-250^{\circ} \mathrm{C}$ of 5 mins. Heat reduced to about $120^{\circ} \mathrm{C}$ and baked for further 10 mins. Each sample removed and cut into desired shape and baked until colden brown. Each sample removed from oven cooled and packed in sealed polyethylene bags.

\subsection{Sensory Evaluation}

The sensory evaluation was done using a twenty member panel of judges drawn from the university community. The procedure was explained to them before commencement. The quality attributes assessed were colour, aroma, taste texture crispiness and overall acceptability. The 9 -point hedenic scale described by Ihekoronye and Ngoddy (1985) was used. The rating was 1- dislike extremely, 2dislike very much 3 - dislike moderately, 4 - dislike slightly, 5 - neither like or dislike, 6 - slightly, 7 - like moderately, 8 - like very much, and 9 - like extremely.

\subsection{Chemical Analysis}

Moisture content, crude protein crude fiber, crude fat content were all determined by the methods of AOAC (2010). While carbohydrate was determined by difference (Ihekoronye and Ngoddy, 1985). Calcium zinc and iron contents were determined by Atomic Absorption spectrophotometer (Model UNICAN 969, solar) as described by Onwuka, 2005. 


\subsection{Statistical Analysis}

Data were analyzed by analysis of variance (Iwe, 2003). The difference between means values was determined by least significant different (LSD) test. Significance were accepted at P $>0.05$.

\section{Results}

The nutrient composition of the traditional and soy-enriched gurudi snack food samples are presented in table 2. The protein levels of the food samples ranged from 5.25\% in traditional gurudi to $7.88 \%$ in the soy-enriched. The carbohydrate levels varied with the traditional gurudi having the highest level $(72.92 \%)$. The traditional gurudi also had higher fat content $(9.80 \%)$ than the soy-enriched (7.80\%). The soy-enriched food sample, however, had higher fiber $(8.61 \%)$ than the traditional gurudi sample $(4.37 \%)$. The traditional gurudi had the highest ash level of $(0.88 \%)$. The soy-enriched had higher level of calcium zinc and iron than the traditional gurudi samples.

The sensory scores of traditional gurudi, which also serves as control followed the same trend as those of the soy-enriched in all the sensory attributes as shown in table 3 (colour, crispiness, taste flavour, overall acceptability as evaluated but different from the crayfish enriched samples. Since there was no significant difference between the traditional gurudi and the soy-enriched samples. Also, the chemical analysis of the traditional gurudi and that of the soy-enriched showed similar results, that is, no significant difference.

Table2. Proximate Composition of Gurudi Snack food Samples

\begin{tabular}{|l|c|c|}
\hline \multicolumn{1}{|c|}{ Nutrient (100g) sample } & Traditional Gurudi (TG) & Soy enriched Gurudi (SEG) \\
\hline Protein (\%) & 5.25 & 7.88 \\
\hline Carbohydrate (\%) & 72.52 & 66.41 \\
\hline Fat (\%) & 9.80 & 7.80 \\
\hline Fibre (\%) & 4.37 & 8.61 \\
\hline Ash (\%) & 0.88 & 0.70 \\
\hline Moisture (\%) & 6.90 & 6.60 \\
\hline Calcium (mg) & 3.02 & 334 \\
\hline Zinc (mg) & 20.96 & 24.97 \\
\hline Iron (mg) & 60.52 & 61.78 \\
\hline
\end{tabular}

Table3. Sensory Scores of Gurudi Snacks

\begin{tabular}{|l|l|l|l|}
\hline & \multicolumn{1}{|c|}{ TG } & \multicolumn{1}{c|}{ CGG } & \multicolumn{1}{c|}{ SEG } \\
\hline Colour & $5.70 \mathrm{x}$ & $4.05 \mathrm{y}$ & $5.55 \mathrm{x}$ \\
\hline Crispiness & $6.15 \mathrm{x}$ & $4.30 \mathrm{y}$ & $5.95 \mathrm{x}$ \\
\hline Taste & $6.0 \mathrm{x}$ & $4.55 \mathrm{x}$ & $5.9 \mathrm{x}$ \\
\hline Flavor & $5.8 \mathrm{x}$ & $4.65 \mathrm{y}$ & $4.45 \mathrm{x}$ \\
\hline Overall acceptability & $5.95 \mathrm{x}$ & $4.25 \mathrm{y}$ & $5.90 \mathrm{x}$ \\
\hline
\end{tabular}

Values in the same row with different superscripts are significantly different at $\mathrm{P}<0.05$ for each snack. $\mathrm{TG}=$ control (traditional Gurudi $\mathrm{CEG}=$ Cray fish - enriched Gurudi; $\mathrm{SEG}=$ Say - enriched Gurudi evaluated on a 9 - point hedonic scale.

\section{DISCUSSION}

The protein content of the soy-enriched gurudi was more that of the traditional gurudi because of the soybean. This shows that adequate supplementation of the traditional snack foods could be beneficial in improving their protein content. Akubor et al (2012) made a similar observation when soyplantain mixtures were used to produce baked products. Reports also show that protein contain doughnuts were prepared using full fat and lecithinated soy flour (5\% leathin), Salunkle et al, (1992). The lower carbohydrates of the soy-enriched gurudithan the traditional ones was because of the supplementation effect of the soybean on the cassava starch component of the gurudi recipe. Soybean is known to contain lower level of carbohydrate than cassava starch.

The fat content of traditional gurudi (9.8\%) was higher than that of the soy enriched $(7.7 \%)$. This ideally should be the reverse is soybean has a unique chemical composition on an average dry matter basis containing $40 \%$ protein and $20 \%$ oil (Nnam 2000). The higher fat content on the traditional gurudi as against th8e soy-enriched may be as a result of better absorption of oil from the margarine used in greasing the baking trays in the process of gurudi production (traditional) as against the soyenriched. 
Notably the soy-enriched recipe mixture absorbed much oil firm the greased pan as that of the Traditional qurudi sample. The soil enriched samples have higher fibre content $(8.61 \%)$ than the traditional qurudi $(4.37 \%)$. This could be due to the supplementation effect of soybean which contains about $31.9 \%$ fibre as reported by Salumlche, et al; 1992 as against $0.2 \%$ maximum fibre content in cassava starch ((Son, 2005). The higher mineral (Calcium, zinc and iron) level of the soyenriched qurudi than the traditional one, further confirms the beneficial effect of supplementation.

\section{CONClusion}

The introduction of the soy-enriched qurudi has made qurudi snack food have promising nutritional attributes. The soy-fortified qurudi contained higher protein level than the traditional qurudi. The enrichment of qurudi with soy-flour could make it valuable in supplying both the macro and micronutrient needs of children adults. The sensory properties of both the traditional and soy-enriched qurudi are dencouraging. There was no significant difference in all the sensory properties used in the study between the traditional and soy-enriched qurudi. From the foregoing, soy-enriched qurudi kwould be advantageous to the Nigerian people to be popularized. Further study on qurudi should be on the popularizing the product.

\section{REFERENCES}

[1] Teltweiller, P. (1991). Snacks-food, fun and fashion, Dragogo Report.

[2] Ekwu, F.C. and Ehirim, C (2008). Comparative evaluation of gari samples produced from fresh cassava roots and dried cassava chips. Nigeria Food Journal, Vol.26, No.260-68.

[3] Ocgenem, O.B. (2009) Comperative analysis of the proximate composition and sensory properties of dakuwa produced in Niger State metropolis, Nigeria. Nigerian food Journal (27(1): 59-65.

[4] The Koronye and Ngoddy, (1985). Food science and Technology for the tropics. Mccmillan publisher Ltd. London Pp. 244, 248-249

[5] AOAC(2010) Association of official Analytical Chemists. Official methods of Analysis. Washington, D.c.

[6] Onwuka, G.i. (2005). Food analysis and instrumentation. Theory and Practice. Naphthal, prints, Lagos, Nigeria.

[7] Iwe, M. (2003). The Science and Technology of soybean chemistry, nutrition, processing, utilization. Handbook.

[8] Akubor, P.i. and Eze, J. i. 2012. quality evaluation and cake making potential of sun and over dried carrot fruit. Int. J. Biosci 2(10) 19-27.

[9] Okaka J.c. and Potter, N. N. (1979) Physico chemical and functional properties of cowpea powder processed to reduce heavy flavour J. Food Sci. 44:1235-1240

[10] Sami, L. B: Maziya-Dixon, J: Akanya, C. I. Okor, Y: alaya, C. v. Eqwuonwu, R. Okechukwu, C: and Dixon, A. (2006). Standards for cassava products and gidelines for Expert: II TA, ibadan, Nigeria 93pp.

[11] Sathe, A.k. Deshphande, S.S. and Sualunkhe, D.K: (1992). Functional properties of hyping seeds protein and protein concentrates, J. food Science 42: 491-498.

[12] Nnem, N.M. (2000) Evaluation of the effect of sprouting on the viscosity proximate composition and mineral content of hungry rice(Digitaria exihis) Flours J. of food science 18:59-62. 